\title{
RURAL METROPOLITAN AREAS \\ AS SITES FOR RECREATIONAL ACTIVITY \\ OF THEIR INHABITANTS AN EXAMPLE \\ OF POZNAN METROPOLIS
}

BERNADETA HOŁDERNA-MIELCAREK, ${ }^{1}$ AGATA BASIŃSKA-ZYCH, ${ }^{2}$ ALICJA KAISER ${ }^{3}$



RECEIVED

ACCEPTED

JEL

CLASSIFICATION

KEYWORDS

ABSTRACT
7 July 2017

1 September 2017

O18, Q19, I12, Z20, Z32, R1

recreational activity, inhabitants of rural areas, sports and recreational infrastructure, Poznań Metropolis

This paper presents motives, types and forms of recreational activity of inhabitants of rural areas, especially location, time and average frequency of undertaking certain types and forms of recreational activity, using particular types of sports and recreational facilities and infrastructure, inhabitants opinions on factors influencing their selection of particular sports and recreation facilities, on recreational offer available in their home location, and satisfaction from the recreational offer in their home location. Research material was collected using diagnostic survey method. The survey included 1,584 of inhabitants of the Poznań Metropolis Association area, including 377 inhabitants of rural areas. Obtained results enabled characterisation of recreational function and actions that could improve development of the recreation and business sector and quality of life in rural areas.

\section{Introduction}

Trends in development of holiday and leisure recreation and tourism of townspeople in areas adjacent to a city or a town, including recreational and leisure functions of those areas, are changing as urban expansion progresses. Globally, urbanization is a strong force with significant effects for human health (Akpinar, 2016, p. 76). While urbanization has increased, human recreational needs have also increased (Karakücük, Gürbüz, 2007, 
p. 17). In cities, part of the demand for the recreational needs of growing populations has been met by providing natural spaces (Kong, Nakagoshi, 2006, pp. 147-164; Byomkesh, Nakagoshi, Dewan, 2012, pp. 45-58). Along with urbanization, decreased quality of life and poorer health for city inhabitants have been reported (The World Bank, 2011; Maller, Townsend, St Leger, Henderson-Wilson, Pryor, Prosser, Moore, 2009, pp. 51-83; Byomkesh et al., 2012, pp. 45-58). In reference to this, many urban residents move to rural areas in search of a better quality of life. On the second hand in recent years, the disseminating of the urban lifestyle among the rural population has also been observed, also in terms of spending free time, physical and recreational activity.

Development of recreational function of rural metropolitan areas is, among others, connected to popularisation of active lifestyle and behavioural patterns during free time, decrease of disproportions in the quality of life, social and economic growth in rural areas, and significance of physical activity for human health. Those issues are a subject matter of scientific research concenring, for instance, sports and recreational infrastructure in relation to lifestyles of townspeople and villagers (Florkiewicz, Zwierko, Krzepota, Łubkowska, Troszczyński, 2011, pp. 341351; Olszewski, Kulikowska, Olszewska, Fiłonowicz, 2014, pp. 133-138), physical activity of young people (Dumuid et al., 2017, pp. 178-183; Guthold, Cowan, Autenrieth, Kann, Riley, 2010, pp. 43-49; Bartoszewicz, Wieczorek, Gandziarki, 2014, pp. 51-59), promotion of health and physical activity in rural areas (Delbani, Hanusz, 2014; Poczta, Malchrowicz-Mośko, 2016, pp. 373-385; Kahn et al., 2002, pp. 73-107; Marcus et al. 2006, pp. 27392752; Reis et al., 2010, pp. 137-145), physical activity in rural and urban areas (Tripathy et al., 2016, pp. 1-10; WHO..., 2004) and analytical papers, including analyses of the Central Statistical Office of Poland concerning Poles participation in sports and physical recreation (GUS, 2017) and quality of life in urban and rural areas (Łysoń, 2015), elaborations of the Ministry of Sports and Tourism of the Republic of Poland concerning Poles' level of physical activity (MSiT, 2016), and works of the Institute for Structural Research and the Ministry of Sports and Tourism of the Republic of Poland concerning social benefits of investments in sports (Baran, Lis, Magda, 2016).

The aim of this paper was identification and characterisation of recreational functions of rural metropolitan areas in the aspect of recreational activity of their inhabitants on the example of the Poznań Metropolis. Recognition of recreational behaviour of the inhabitants and ways of using the recreational offer by them can serve as the grounds of determination of rural areas' recreational function and actions supporting development of recreation. In wider context, the described issue can be attributed to improving quality of life, development of business initiatives, and promotion of physical and recreational activity in rural metropolitan areas.

\section{Method}

The paper is of empirical character. The material comprised the results of a survey concerning physical and recreational activity of the inhabitants of rural area of the Poznań Metropolis Association and included a sample of 377 persons (rural communes). It was a part of broader research conducted from March to June 2016 among 1,584 inhabitants of the Poznań Metropolis in which diagnostic survey method was used (survey was conducted using standard questionnaire). Spacial range of the survey included Poznań Metropolis understood as an area of the metropolitan city of Poznań, 17 communes of the Poznań district, and communes associated in the Poznań Metropolis Association: Oborniki, Śrem, Szamotuły, and Skoki. 
Sample size was determined assuming maximal error of $0.05(\alpha=0.05)$. Quota-proportional sampling was used to select persons for the sample. The research is representative - representativity of the sample was evaluated considering sex, age, and level of education. Data obtained from the Central Statistical Office of Poland were used to determine sample size and structure using the quota-proportional method. Conclusions were drawn based on the analysis of indicators of the number of indications of a certain questionnaire item per 100 persons. As the obtained material was very extensive, the authors decided to include in this paper only several aspects of recreational activity of the inhabitants of the Poznań Metropolis.

\section{Results}

Types of physical recreation the most popular in rural areas of the Poznań Metropolis include: 1) hiking/ walking (44.4 per 100 persons), 2) cycling (35.6 per 100 persons), and swimming (23.6 per 100 persons). Among those activities, the smallest difference between villagers and townspeople were noted for cycling. Fitness (18.1 per 100 persons) and other activities (14.4 per 100 persons) are also willingly undertaken by villagers (Figure 1).

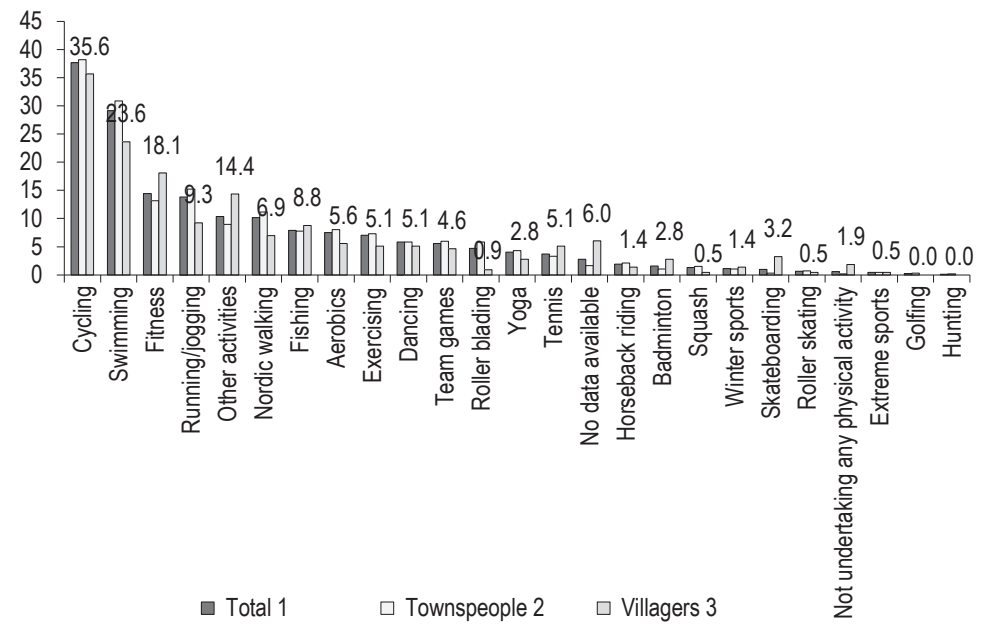

Figure 1. Types of physical activity of Poznań Metropolis's inhabitants

Source: own survey's study $1: \mathrm{N}=1,584 ; 2: \mathrm{N}=1,207 ; 3: \mathrm{N}=377$.

Inhabitants of rural areas of the Poznań Metropolis more often than townspeople undertake recreational activity around lakes located outside towns/cities (17.6\% of villagers and $3.9 \%$ of townspeople), in landscape parks ( $14.4 \%$ of villagers and $5.4 \%$ of townspeople), and in rural areas, such as fields, meadows, and pastures $(9.7 \%$ of villagers and $3.0 \%$ of townspeople) (Figure 2). It is worth noticing that despite convenient availability of such sites, $27.3 \%$ of villagers recreate in green areas of towns/cities: squares, greens, parks and the share of such sites in the total is the highest. 




Figure 2. Types of sites of undertaking recreational activity in home location (\%)

Source: own survey's study 1 : $N=1,584 ; 2: N=1,207 ; 3: N=377$.

According to declarations of the respondents, inhabitants of rural areas undertake physical activity mainly in their home locations. Value of the indicator of undertaking physical activity during weekends ranges from 40.6 to 60 per 100 persons, while during working days, from 36.3 to 67.0 per 100 persons. During working days physical activity is the most often undertaken before noon (67 per 100 persons) and in the afternoon (62 per 100 persons), while during weekends, in the morning ( 60 per 100 persons), evening (55 per 100 persons), and in the afternoon (55 per 100 persons). The inhabitants of rural areas included in the survey usually do not take advantage of the recreational offer of the city of Poznań and this includes working days and weekends. Also, they do not undertake any physical activity in other communes.

Moreover, $26.3 \%$ of villagers engage in physical recreation several times a month outside weekends, $13.3 \%$ several times per month during weekends, $10.3 \%$ on every weekend, and $7.2 \%$ every day. However, $42.7 \%$ of villagers does not participate in physical recreation (Figure 3).

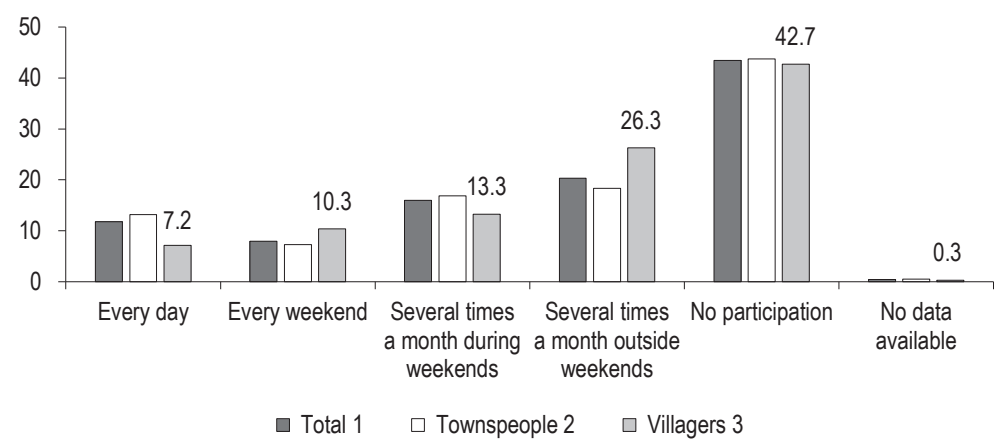

Figure 3. Time and frequency of undertaking physical recreation inhabitants of Poznań Metropolis (\%)

Source: own survey's study 1: $N=1,584 ; 2: N=1,207 ; 3: N=377$. 
Next interesting issue of the study was motives behind undertaking recreational activity of rural inhabitants of Poznań metropolis (Figure 4). The main motives behind undertaking recreational activity by villagers include: improving physical fitness (62.0 per 100 persons), resting, relaxing (60.6 per 100 persons), improving health (41.2 per 100 persons), achieving attractive silhouette (27,8 per 100 persons), relieving stress (26.9 per 100 persons), and spending time with family, friends (20.4 per 100 persons). Villagers' motives are similar to those declared by townspeople. The two first motives were declared more often by villagers than townspeople, while relieving the stress and spending time with family were indicated less often in comparison to townspeople.

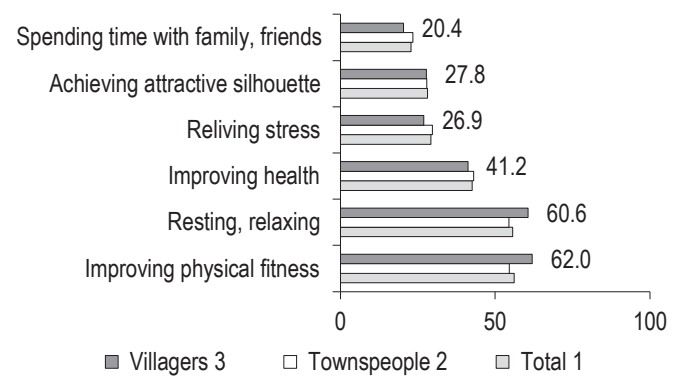

Figure 4. Motives behind undertaking recreational activity by villagers in Poznań Metropolis (per 100 persons)

Source: own survey's study 1: $N=1,584 ; 2: N=1,207 ; 3: N=377$.

The average time of reaching the site of physical recreation by villagers is usually less than 15 minutes during working days ( $45.8 \%$ of respondents) and during weekends (34.3\% of respondents). Every fifth inhabitant indicated up to 30 minutes (23.1\%) as the time needed for reaching the site of physical recreation during weekends. The results between surveyed villagers and townspeople are similar (Table 1).

Table 1. The average time of reaching the physical recreation site in opinion of Poznań Metropolis inhabitants (\%)

\begin{tabular}{lcccccc} 
& \multicolumn{2}{c}{ Total (1) } & \multicolumn{2}{c}{ Townspeople (2) } & \multicolumn{2}{c}{ Villagers (3) } \\
\cline { 2 - 7 } & working days & weekends & working days & weekends & working days & weekends \\
\hline Less than 15 min. & 48.3 & 36.1 & 49.4 & 37.0 & 45.8 & 34.3 \\
About 30 min. & 15.3 & 24.8 & 15.8 & 25.2 & 12.5 & 23.1 \\
About 45 min. & 3.6 & 6.6 & 3.3 & 7.0 & 4.6 & 5.6 \\
About 60 min. & 0.8 & 3.0 & 0.9 & 3.7 & 0.5 & 0.9 \\
Over 60 min. & 0.1 & 0.6 & 0.1 & 0.7 & 0.0 & 0.0 \\
No data available & 32.0 & 28.9 & 30.4 & 26.3 & 36.6 & 36.1 \\
\hline
\end{tabular}

Source: own survey's study 1: $\mathrm{N}=1,584 ; 2: \mathrm{N}=1,207 ; 3: \mathrm{N}=377$.

The opinions of inhabitants of rural and urban areas of Poznań metropolis on the use of sports and recreational facilities in their home location were also examined (Figure 5). Small-scale facilities in their home location are the most often chosen by all of the inhabitants of the Poznań Metropolis (46.8 per 100 persons) among whom 
inhabitants of rural areas prevail (54.6 per 100 persons). While big-scale chain facilities in their home location are significantly more often chosen by townspeople (20.9 per 100 persons) than villagers.



Figulp 5. Sports and recreational facilities preferred by villagers in Poznań Metropolis (per 100 persons)

Source: own survey's study 1: $N=1,584 ; 2: N=1,207 ; 3: N=377$.

On average, inhabitants of rural areas use fitness clubs and gyms in home location 11 times a month, children's playgrounds about 10 times, and skate parks and tennis courts about 7 times a month (Table 2). The results are similar to average frequencies of using sports and recreational infrastructure in home location by all of the inhabitants of the Poznań Metropolis. It is noteworthy that villagers less often use grass football fields and outdoor gyms. The respondents living in rural areas did not declare using the following facilities: climbing walls, horseback riding facilities, cycle speedway tracks, ropes courses, golf fields.

Table 2. Usage of sports and recreational infrastructure in home location in opinion of Poznań Metropolis inhabitants (per 100 persons)

\begin{tabular}{lccc}
\hline \multicolumn{1}{c}{ Type of infrastructure } & The total 1 & Townspeople 2 & Villagers 3 \\
\hline \multicolumn{1}{c}{1} & 2 & 3 & 4 \\
\hline Grass football fields & 4.30 & 4.70 & 2.60 \\
Multifunctional sports fields & 3.86 & 4.06 & 3.40 \\
Fields for sports requiring small space & 2.60 & 2.00 & 2.50 \\
Sports and entertainment halls & 4.20 & 4.88 & 2.22 \\
Gymnasiums & 5.40 & 5.52 & 4.10 \\
Bowling alleys & 1.50 & 1.62 & 1.20 \\
Indoor swimming pools & 3.90 & 3.97 & 3.79 \\
Outdoor swimming pools & 2.90 & 3.00 & 3.00 \\
Tennis courts & 6.20 & 5.70 & 7.43 \\
Squash facilities & 4.80 & 4.13 & 6.67 \\
Climbing walls & 1.90 & 1.90 & 0.00 \\
Skate parks & 6.80 & 5.75 & 7.60 \\
\hline
\end{tabular}




\begin{tabular}{lccc}
\hline & 1 & 2 & 3 \\
\hline Horseback riding facilities & 4.00 & 4.00 & 0.00 \\
Cycle speedway tracks & 0.00 & 0.00 & 0.00 \\
Outdoor gyms & 4.05 & 4.14 & 1.50 \\
Ropes courses & 1.60 & 1.60 & 0.00 \\
Children's playgrounds & 7.91 & 7.58 & 9.86 \\
Golf fields & 5.50 & 5.50 & 0.00 \\
Alpine slides & 0.00 & 0.00 & 0.00 \\
Ski slopes & 2.09 & 2.33 & 1.00 \\
Shooting ranges & 2.43 & 2.43 & 0.00 \\
Watering places & 3.04 & 3.33 & 2.00 \\
Artificial skating rinks & 2.30 & 2.33 & 2.00 \\
Riverside hostels & 5.40 & 6.60 & 2.75 \\
Other & 12.52 & 13.60 & 8.50 \\
\hline
\end{tabular}

Source: own survey's study 1: $N=1,584 ; 2: \mathrm{N}=1,207 ; 3: \mathrm{N}=377$.

Furthermore, one of the interesting issue were Poznań Metropolis villagers' criteria of choosing sports and recreational facilities. For the inhabitants of rural areas of the Poznań Metropolis the most important criteria of choosing a facility are: proximity (78.6 per 100 persons), price (53.8 per 100 persons), convenient communication (42.8 per 100 persons), and quality of services (35.3 per 100 persons). In comparison with the townspeople, for the villagers the proximity and convenient communication are more important.

Analysis of villagers' average monthly expenses connected to physical and recreational activity divided into seasons allows to conclude that in winter (PLN 453.2), spring (PLN 390.8), and autumn (PLN 387,3) they are higher than the expenses of townspeople. Moreover, in spring and autumn the difference between villagers' and townspeople's expenses amounts to PLN 99.0 and in winter to PLN 66.00. While summer expenses of villagers and townspeople are similar and amount to PLN 654.3 and PLN 670.0, respectively.

Opinions of villagers concerning sports and recreational offer in their home location do not differ significantly from the opinions of all the inhabitants of the Poznań Metropolis (Figure 6). Almost a half of villagers (48.3\%) thinks that the offer is good and $28 \%$ assigned a medium to it.

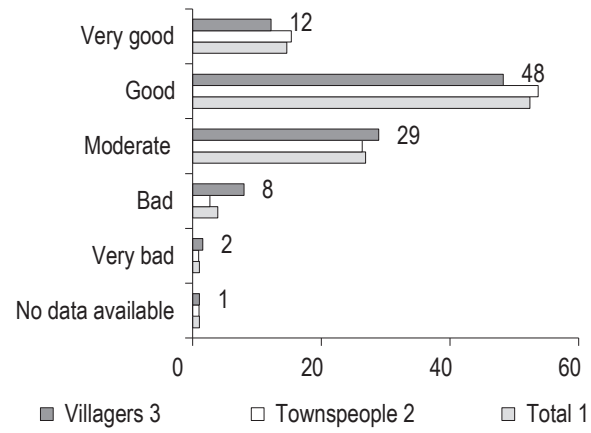

Figure 6. Poznań Metropolis inhabitant's opinion on home location's sports and recreational offer (\%)

Source: own survey's study 1: $N=1,584 ; 2: N=1,207 ; 3: N=377$. 


\section{Conclusions}

The obtained results enabled recognition of recreational function of rural areas of the Poznan Metropolis and recreational behaviour of their inhabitants as well as determination of the range of actions that would create good conditions for physical activity, improve quality of life in rural areas, and that would facilitate development of business initiatives.

Recreational function of rural areas of the Poznań Metropolis for their inhabitants is very important. Villagers very willingly engage in recreational activity in those areas and are able to reach those sites within 15 minutes.

It can be concluded that physical activity is a part of life of the inhabitants of rural areas of the Poznan Metropolis. Over half of inhabitants (57\%) declares undertaking recreational activity. Villagers seem to lead healthy lifestyles and take care of their physical fitness as people aware of the importance of resting and relaxing as well as fitness.

The attractiveness of landscape parks, rural areas, and lakes enables undertaking recreational activities such as hiking and cycling which were indicated more often by villagers that townspeople. However, predilection of villagers for undertaking recreational activity in urban green areas (squares, greens, and parks) and using sports and recreational facilities (fitness clubs, playgrounds, and skate parks) is noteworthy. This can suggest popularisation of urban model of living.

In addition, described recreational behaviour of villagers, the level of expenses on recreation, and proximity declared by most inhabitants as the main criterion of choosing sports and recreational facilities, can serve as pointers on the directions of development of businesses of the physical recreation services sector, e.g. development of infrastructure and active forms of recreation that are willingly used and undertaken by the inhabitants. This can also be the ground for further researches concerning creation of conditions for development of other forms of physical activity.

The benefits of the study can refer to the issues related to the formulation of regional strategies to create conditions for the development of the leisure sector and support local socio-economic initiatives, such as: development of recreational infrastructure, recreation services and sports and leisure activities, which may have an impact on the development of entrepreneurship and job creation.

Development of the sector of recreation in rural areas is a chance for improving the quality of life there, i.e. creating convenient conditions for undertaking recreational activity as well as vocational activation and improving professional competences of the inhabitants. It is also noteworthy that promotion of physical activity and active life style improves health of an individual person but is also beneficial for the entire community.

\section{Acknowledgement}

Project funded as part of specific subsidy for maintaining research capacity from the resources of Ministry of Science and Higher Education 2016 - Metropolitan Region as Space for Recreational Penetration based on Poznań Metropolis in 2015-2016 under supervision of Agata Basińska-Zych, PhD in WSB University in Poz-nań (decision number 27090/E534/S/2016). 


\section{References}

Akpinar, A. (2016). How is Quality of Urban Green Spaces Associated with Physical Activity and Health? Urban Forestry \& Urban Greening, 16, 76-83.

Baran, J., Lis, M., Magda, I. (2016). Ocena korzyści społecznych inwestycji w sport w odniesieniu do ponoszonych kosztów. Analytical report. Instytut Badań Strukturalnych. Warszawa: Ministerstwo Sportu i Turystyki.

Bartoszewicz, R., Wieczorek, M., Gandziarki, K. (2014). Zróżnicowanie środowiskowe aktywności ruchowej młodzieży gimnazjalnej w kontekście strategii zrównoważonego rozwoju. Akademia Wychowania Fizycznego we Wrocławiu. Academic dissertations.

Byomkesh, T., Nakagoshi, N., Dewan, A.M. (2012). Urbanization and green spacedynamics in Greater Dhaka, Bangladesh. Landscape Ecol. Eng., 8, 45-58.

Delbani, H., Hanusz, H. (2014). Participation in tourist and recreational activities of women aged 50+ living in rural areas. In: D. Kozłowska (ed.), Recreation, Tourism and Traditions in Rural Areas (pp. 39-50). Białystok: Department of Publications and Publications of the School of Physical Education and Tourism in Bialystok.

Dumuid, D. et al. (2017). Health-Related Quality of Life and Lifestyle Behavior Clusters in School-Aged Children from 12 Countries. The Journal of Pediatrics, 183, 178-183.

Florkiewicz, B., Zwierko, T., Krzepota J., Łubkowska W., Troszczyński J. (2011). Styl życia mieszkańców miast i wsi w regionie zachodniopomorskim a baza sportowa i rekreacyjna. Zeszyty Naukowe Uniwersytetu Szczecińskiego, 689, Ekonomiczne Problemy Usług, 78, 341-351.

Guthold, R., Cowan, M.J., Autenrieth, C.S., Kann, L., Riley, L.M. (2010). Physical Activity and Sedentary Behavior among Schoolchildren: a 34-country comparison. J Pediatr., 157, 43-49.

Kahn, E.B. et al. (2002). The Effectiveness of Interventions to Increase Physical Activity. A Systematic Review. Am J Prev Med., 22 (4, Suppl), 73-107.

Karakücük, S., Gürbüz, B. (2007). Rekreasyon ve Kent(li)lesme. Gazi Kitabevi, Ankara.

Kong, F., Nakagoshi, N. (2006). Spatial-temporal Gradient Analysis of Urban Greenspaces in Jinan. Chin. Landscape Urban Plann., $3(78), 147-164$.

Lysoń, P. (2015). Jakość życia na obszarach miejskich i wiejskich. Warszawa: Departament Badań Społecznych i Jakości Życia. GUS.

Maller, C., Townsend, M., St Leger, L., Henderson-Wilson, C., Pryor, A., Prosser, L., Moore, M. (2009). Healthy Parks, Healthy People: the Health Benefits of Contact with Nature in a Park Context. George Wright Forum, 2 (26), 51-83.

Marcus, B.H. et al. (2006). Physical Activity Intervention Studies: What we Know and What we Need to Know: a Scientific Statement from the American Heart Association Council on Nutrition, Physical Activity, and Metabolism (Subcommittee on Physical Activity); Council on Cardiovascular Disease in the Young; and the Interdisciplinary Working Group on Quality of Care and Outcomes Research. Circulation, 24 (114), 2739-2752.

Olszewski, B., Kulikowska, E., Olszewska, M., Fiłonowicz, T. (2014) Investments in Sports, Tourism and Recreation Infrastructure in the years 2011-2014 in the municipality Turośń Kościelna. In: D. Kozłowska (ed.), Recreation, Tourism and Traditions in Rural Areas (pp. 133-138). Białystok: Department of Publications and Publications of the School of Physical Education and Tourism in Bialystok

Poczta, J., Malchrowicz-Mośko, E. (2016). Turystyka sportowa jako czynnik promocji zdrowia i aktywności fizycznej na obszarach wiejskich w Polsce. Handel Wewnętrzny, 6 (635), 373-385.

MSiT (2016). Poziom aktywności fizycznej Polaków. Ministerstwo Sportu i Turystyki. Warszawa: Kantar Public. Retrieved from: https:/l www.msit.gov.pl/download.php?s=1\&id=11918 (10.11.2017).

Reis, R.S. et al. (2010). Promoting Physical Activity Through Community-Wide Policies and Planning: Findings From Curitiba, Brazil. Journal of Physical Activity and Health, 7 (2 Suppl), 137-145.

The World Bank (2011). Climate Change, Disaster Risk, and the Urban Poor: Cities Building Resilience for a Changing World. The International Bank for Reconstruction and Development/The World Bank, Washington, USA.

Tripathy, J.P. et al. (2016). Urban Rural Differences in Diet, Physical activity and Obesity in India: are we Witnessing the Great Indian Equalisation? Results from a Cross-sectional STEPS Survey. BMC Public Health, 16 (816), 1-10. 
GUS (2017). Uczestnictwo w sporcie i rekreacji i rekreacji ruchowej w 2016. Informacje i opracowania statystyczne. Warszawa: GUS. WHO Diet and physical activity: a public health priority [Internet] (2004). World Health Organization. Retrieved from: http://www.who.int/ dietphysicalactivity/background/en (30.04.2017)

Cite this article as: Hołderna-Mielcarek, B., Basińska-Zych, A., Kaiser, A. (2017). Rural metropolitan areas as sites for recreational activity of their inhabitants an example of Poznan agglomeration. European Journal of Service Management, 3 (23), 21-30. DOI: 10.18276/ejsm.2017.23-03. 